\title{
Pengaruh Kalimat Motivasi dan Gaya Kepemimpinan Terhadap Kinerja Karyawan
}

\author{
Sri Andika Putri ${ }^{1}$ dan Fitria Setyaningrum ${ }^{2}$ \\ Program Studi Akuntansi, Universitas Tribhuwana Tunggadewi \\ Email: sriandika66@gmail.com
}

\begin{abstract}
ABSTRAK
Kalimat motivasi merupakan salah satu cara pemimpin untuk memberikan dorongan kepada karyawan agar bekerja sesuai dengan target yang diinginkan. Motivasi dalam bentuk kalimat ini lebih efisien digunakan selain menghemat dana, juga menghemat waktu dan tenaga. Pemimpin dengan gaya kepemimpinan yang situasional akan menjadi pemimpin yang diinginkan di era sekarang ini.

Penelitian ini merupakan penelitian kualitatif yang dilaksanakan di Kecamatan Lowokwaru Kota Malang. Sampel yang diambil adalah UMKM yang dipilih secara acak. Hasil penelitian menunjukkan bahwa motivasi sangat penting dilakukan oleh pimpinan perusahaan. Gaya kepemimpinan yang diharapkan karyawan yaitu gaya kepemimpinan yang situasional dimana gaya ini mudah berbaur dengan keadaan yang terjadi.
\end{abstract}

\section{Kata Kunci: Kalimat Motivasi, Gaya Kepemimpinan, Kinerja Karyawan}

\section{PENDAHULUAN}

Karyawan merupakan komponen penting dalam sebuah perusahaan. Perusahaan tidak akan menghasilkan hasil produksi atau jasa jika karyawan dalam perusahaan tersebut tidak berjalan dengan baik bahkan jika karyawan tidak ada sama sekali.

Karyawan dalam perusahaan wajib diberikan motivasi dan arahan yang positif agar mereka menjalankan perintah atasan atau pemimpin perusahaan dengan baik. Tidak aka nada sebuah perusahaan yang dapat bertahan jika tidak memberikan motivasi yang baik secara terus menerus.

Pemimpin dalam perusahaan memiliki beban moral yang tinggi untuk memberikan motivasi kepada karyawan. Motivasi yang diberikan dapat berupa reward berbentuk barang atau reward dalam bentuk ungkapan sanjungan.

Reward yang diberikan antara seorang karyawan dengan karyawan yang lain bisa berbeda-beda. Reward yang paling tinggi dalam dunia kerja secara manajemen adalah reward jabatan. Dengan memberikan jabatan yang lebih tinggi sebagai bentuk apresiasi atas kinerja karyawan yang sudah berhasil mencapai target yang diinginkan oleh perusahaan.

Target dapat tercapai oleh setiap karyawan jika karyawan memiliki motivasi yang tinggi untuk mencapai target tersebut. Cara yang paling sederhana untuk meningkatkan motivasi karyawan yaitu 
dengan memberikan ungkapan-ungkapan atau kalimat yang dapat membangkitkan semangat bekerja karyawan.

Kalimat yang dapat membangkitkan semangat kerja karyawan dalam lingkungan kerja secara umum dikenal juga dengan sebutan kalimat motivasi. Kalimat motivasi dapat diberikan setiap saat jika memang dirasa penting oleh pimpinan perusahaan. Hal ini dilakukan agar target perusahaan dapat tercapai dengan baik bahkan jika memungkinkan tercapai sebelum waktu yang telah ditentukan.

Cara seorang pimpinan memberikan kalimat motivasi juga berbeda-beda tergantung dengan cara kepemimpinan dari seorang pemimpin. Ada pemimpin yang memilih cara demokratis, visioner atau dengan cara choacing.

Gaya kepemimpinan seorang pemimpin sangat menentukan keberhasilan sebuah perusahaan. Target yang hendak dicapai dengan mudah dapat diraih dengan gaya kepemimpinan yang luwes, apalagi pada era sekarang ini. Karyawan tidak akan merasa dihargai dan memiliki kinerja yang baik jika pemimpin tidak bisa mendorong motivasi kerja karyawannya. Dorongan yang sangat penting dan menjadi kunci utama keberhasilan pemimpin memotivasi pada saat sekarang adalah dengan memberikan kalimat motivasi secara terus menerus dan tidak menegur karyawan dengan cara yang kasar atau dengan peraturan yang begitu ketat dan kaku.

\section{TUJUAN PENELITIAN}

Penelitian ini bertujuan untuk mengetahui sejauh mana pengaruh gaya kepemimpinan yang dimiliki oleh seorang pimpinan terhadap kinerja karyawan dan seberapa besar pengaruh kalimat motivasi terhadap semangat dan produktivitas kerja karyawana pada UMKM yang ada di Kecamatan Lowokwaru Kota Malang.

\section{METODE PENELITIAN}

Penelitian ini menggunakan jenis penelitian kualitatif dimana peneliti merupakan instrument kunci dalam penelitian (Sugiyono, 2005). Menurut Moleang (2005) penelitian kualitatif adalah penelitian dengan maksud memahami keadaan atau fenomena yang dialami oleh subjek penelitian, contohnya penelitian tentang perilaku, motivasi yang disampaikan dengan bentuk deskriptif.

Penelitian ini dilakukan di beberapa UMKM yang ada di Kota Malang. Sampel yang diambil hanya 10 UMKM yang berada di Kecamatan Lowokwaru. Pengambilan sampel dilakukan secara acak tanpa memperhatikan besar dan jumlah karyawan yang dimiliki serta lokasi UMKM.

Data penelitian dikumpulkan dengan cara kuesioner yang dibagikan kepada pemimpin 
dan karyawan perusahaan atau UMKM. Kuesioner yang diberikan kepada pemimpin untuk mengetahui gaya kepemimpinan yang digunakan serta sejauh mana pemimpin memberikan kalimat motivasi kepada karyawan sehingga karyawan terdorong untuk melakukan tindakan yang lebih baik lagi. Kuesioner yang diberikan kepada karyawan untuk mengetahui sejauh mana karyawan merasa mendapatkan motivasi dari pimpinan dan sejauh mana karyawan merasa target kerjanya tercapai dengan baik.

\section{PEMBAHASAN}

A. Manajemen Sumber Daya Manusia

Menurut Bohlander (2013), yang dikatakan dengan manajemen sumber daya manusia yaitu sebuah proses dari pengaturan kemampuan seseorang dalam hal ini pimpinan untuk mendapatkan tujuan perusahaan. Seni mengatur peranan tenaga kerja yang satu dengan yang lain agar efektif fan efisien ini bukanlah hal yang mudah.

Pengaturan tenaga kerja menjadi satu kesatuan yang utuh ini bukanlah hal yang mudah. Apalagi jika pimpinan tidak bisa bersikap profesional, lebih banyak melibatkan perasaan, bukan sikap secara objektif.

Karyawan harus mendapat perhatiaan khusus dari pimpinan, baik secara pribadi atau secara gabungan dalam bentuk kelompok kecil per unitnya. Gunanya yaitu agar capaian target dari perusahaan dapat berjalan dengan baik.

\section{B. Motivasi Kerja}

Menurut Handoko (2010) motivasi merupakan keadaan yang berada dalam diri seseorang untuk mencapai tujuan atau target tertentu. Keadaan ini juga mendorong seseorang untuk terus bergerak sesuai dengan apa yang ia inginkan.

Motivasi ini merupakan potensi utama dan sangat besar pengaruhnya terhadap seseorang untuk bergerak dan melakukan sesuatu sesuai dengan apa yang ingin dicapainya. Motivasi bisa dari dalam diri sendiri dan bisa dari luar diri sendiri.

Motivasi yang diberikan oleh pimpinan dalam lingkungan kerja sangat mempengaruhi capaian kerja setiap karyawan. Karena itu pimpinan dalam menjalankan tugasnya harus memiliki gaya kepemimpinan yang disukai oleh karyawannya. Sehingga seduanya bisa berjalan beriringan, tidak ada perbedaan persepsi dalam mencapai target perusahaan.

Rendahnya motivasi yang diberikan oleh pimpinan juga sangat berdampak terhadap hasil produk atau jasa yang dihasilkan oleh perusahaan. Jika motivasi yang diberikan tidak mengena pada 
pribadi karyawan maka kinerja karyawan tidak akan meningkat. Namun sebaliknya, jika motivasi yang diberikan pimpinan secara terus menerus hingga sampai pada perubahan mindset karyawan maka secara otomatis karyawan akan berubah sesuai dengan apa yang diterimanya dengan baik.

\section{Motivasi Kerja}

Motivasi dalam dunia kerja akan dipengaruhi oleh beberapa hal yaitu fisiologis, keamanan, lingkungan sosial, serta penghargaan yang diberikan.

Faktor fisiologis berkaitan erat dengan kebutuhan pangan, sandang, serta kebutuhan jasmani yang dirasakan langsung oleh karyawan. Secara logika jika semua hal ini dapat dipenuhi oleh perusahaan maka dampak positif dalam bentuk kinerja yang meningkat akan didapatkan perusahaan dari karyawannya. Rasa aman dan tentram selama bekerja juga dibutuhkan karena jika karyawan tidak merasa aman atau merasa tertekan maka kinerja yang dihasilkan akan berdampak negatif. Jika hal ini terjadi maka pimpinan berkewajiban memperbaiki keadaan tersebut. Mungkin dengan cara memberikan arahan dan motivasi secara personal atau memberikan pengertian tentang keadaan dilingkungan kerja karyawan.
Lingkungan sosial yang baik akan memberikan motivasi yang baik juga terhadap karyawan dalam melaksanakan pekerjaannya. Jika lingkungan sosial dibangun dengan hal-hal yang positif dan bersifat membangun sesuai dengan target perusahaan maka perusahaan dan pimpinan tidak akan kesulitan mengatur karyawan dan memikirkan keberlangsungan produk atau jasa yang akan diraih perusahaan di masa yang akan datang.

Penghargaan yang diberikan kepada karyawan berdampak positif terhadap kinerja karyawan. Penghargaan dapat berupa kontrol harga diri karyawan dengan cara memberikan sanjungan atas setiap capaian yang diraih oleh masingmasing karyawan, memberikan kebebasan kepada karyawan untuk bertindak dan bersikap sesuai dengan yang diinginkan karyawan namun masih dalam batas yang telah disepakati sebelumnya pada saat penerimaan karyawan.

Faktor lain dari motivasi kerja yaitu personal atau individu karyawan sendiri, pimpinan, tim, dan sistem.

Personal karyawan berpengaruh pada kinerja karena ini terkait dengan kemampuan karyawan sendiri dalam melaksanakan tugasnya. Potensi diri yang dimiliki apakah sesuai dengan kerjaan 
yang sedang digeluti, apakah karyawan mampu menyelesaikan pekerjaan yang diberikan oleh pimpinan. Karena jika karyawan tidak memiliki keahlian apaapa dibidangnya tetapi memaksakan diri untuk tetap bekerja, akan berdampak terhadap hasil kerja yang tidak bagus. Sebaliknya jika seorang akuntan bekerja sesuai sengan bidangnya di kantor akuntan publik maka kemungkinan besar ia akan menghasilkan pekerjaan yang sangat baik.

Pimpinan yang luwes dan dapat bekerja sama serta menjadi panutan bagi karyawan akan memberikan pengaruh yang sangat baik bagi perusahaan dan karyawan. Terutama terhadap hasil produksi dan jasa yang dijual oleh perusahaan. Pimpinan yang sering memberikan motivasi yang positif akan disenangi karyawan dan akan menjadikan karyawan bergerak dengan sendirinya mencapai target yang diinginkan perusahaan. Kalimat motivasi yang diberikan tidak harus berat, cukup dengan kata-kata yang sederhana namun karyawan menjadi sangat dihargai.

Kerjasama tim sangat mempengaruhi kinerja baik atau buruknya seorang karyawan. Tim yang solid dan saling mendukung akan menjadikan setiap karyawan betah bekerja meskipun terkadang belum mampu menyelesaikan semua tugas sendiri dengan baik. Berkat kerjasama tim yang baik maka pekerjaan yang sedikit sulit bisa diatasi dengan baik. Adanya rasa saling membantu antar karyawan membuat pekerjaan dan target kerja dengan cepat terselesaikan tanpa dibantu oleh atasan langsung.

Sistem kerja yang lebih flexible biasanya lebih diminati dari pada sistem kerja yang kaku. Banyak karyawan mencari tempat kerja yang seperti ini. Rata-rata mereka beralasan bahwa dengan waktu yang bisa dinego maka bukan hanya satu pekerjaan yang dapat dicapai tapi bisa dua atau tiga pekerjaan bisa berjalan secara bersamasama dengan baik. Sistem lingkungan kerja yang lebih manusiawi tentu saja lebih disukai oleh karyawan.

\section{Indikator Kinerja Karyawan}

Mahsun (2006) menyampaikan bahwa kinerja karyawan merupakan penilaian tentang proses kemajuan pekerjaan dengan tujuan atau sasaran yang hendak dicapai baik itu berupa produk atau jasa. Dalam mengukur kinerja karyawan ada beberapa hal yang harus diperhatikan yaitu (1) kuantitas, (2) kualitas, (3) efisiensi waktu, (4) Kehadiran, dan (5) kerja sama.

Kuantitas yang dimaksud dalam mengukur kinerja karyawan yaitu berapa jumlah produksi yang dapat dicapai oleh 
karyawan dalam bekerja. Jika target produksi yang diharapkan tercapai dengan baik maka kinerja karyawan dapat digolongkan ke dalam kategori baik atau sebaliknya jika jumlah produksi yang diharapkan tidak mencapai target maka kinerja karyawan dianggap jelek atau kurang baik. Apabila jumlah produksi yang diharapkan melebihi target maka kuantitas kinerja karyawan dianggap sangat baik.

Kualitas karyawan dikategorikan sangat baik apabila hasil produksi yang diharapkan melebihi kualitas atau minimal semua hasil produksi berhasil dikerjakan dengan standar yang sudah ditentukan. Kualitas karyawan dianggap baik apabila kualitas produksi yang dihasilkan rata-rata memiliki kualitas yang sesuai dengan standar yang ditentukan, apabila ada kesalahan itu pun tidak banyak. Dan kualitas karyawan dianggap kurang baik apabila hasil produksi yang diharapkan tidak memuaskan atau kualitas produksi banyak yang tidak sesuai standar yang ditentukan.

Karyawan juga diukur dari ketepatan waktu dalam bekerja. Menggunakan waktu dengan sangat efisien sangatlah penting dalam perusahaan. Terutama pada usaha UMKM. Kehadiran karyawan tepat waktu dan menyelesaikan pekerjaan sesuai dengan waktu yang ditentukan sangat membantu perkembangan dan kemajuan UMKM ke depannya. Memang harus diakui masih banyak UMKM yang tidak menerapkan aturan seperti layaknya perusahaan, namun sudah ada beberapa yang mulai mencontoh peraturanperaturan perusahaan besar untuk meningkatkan kualitas dan kemajuan UMKMnya. Pemimpin perusahaanlah yang harus mengambil peran besar dibagian ini. Jika pemilik UMKM atau pemimpin perusahaan disiplin dalam hal waktu maka tidak aka nada karyawan yang tidak disiplin karena contoh teladan dari atasan langsung mereka miliki.

Kehadiran karyawan berpengaruh besar pada hasil produksi UMKM. Jika 1 orang karyawan tidak hadir pada hari tertentu tentu saja jumlah produksi menurun pada hari tersebut. Karena UMKM rata-rata karyawannya terbatas maka hal ini akan berpengaruh juga terhadap keberlanjutan perusahaan atau UMKM. Kehadiran ini juga menjadi tolak ukur loyalitas karyawan terhadap perusahaan dan juga berkaitan erat dengan pemanfaatan efisiensi waktu yang dimiliki oleh karyawan dan perusahaan.

Kerjasama dalam melaksanakan proses produksi dan bekerja akan berdampak positif terhadap perusahaan yang dikelola. Untuk itulah pimpinan harus 
bisa memiliki kemampuan unutk membangun karakter kerja sama pada setiap karyawan. Pemimpin harus mampu menjadikan karyawan yang sulit bekerja sama menjadi bisa bekerja sama dengan baik. Begitu juga sebaliknya karyawan dinilai baik apabila mampu bekerja dalam tim dengan baik karena pada dasarnya UMKM bisa meningkat bahkan berubah menjadi perusahaan besar tidak lepas dari kerjasama antar karyawan (Desky, 2014).

E. Hubungan Motivasi Kerja dengan Kinerja Karyawan

Motivasi kerja memiliki pengaruh besar terhadap hasil yang diharapkan oleh perusahaan. UMKM yang memiliki aturan sederhana dapat menjadi besar jika motivasi yang diberikan kepada karyawan diterima dengan baik oleh karyawan. Dengan penerimaan motivasi yang baik secara tidak langsung dorongan untuk menghasilkan kualitas dan kuantitas yang baik akan tercapai dengan sendirinya. Semua hal yang berkaitan dengan kualitas produksi akan menjadi amanah tersendiri oleh karyawan dalam bekerja.

Pemimpin berkewajiban memberikan motivasi ini setaip saat meskipun pada saat tertentu kinerja semua karyawan dianggap sudah sangat memuaskan. Motivasi dapat diberikan dalam bentuk kalimat-kalimat yang membuat karyawan semakin semangat dalam bekerja, misalnya kalimat "Jika produksi kita melebihi target dalam tiga bulan berturutturut berarti kita menikmati sedikit tambahan gaji sebagai bagian dari keuntungan usaha kita selama ini" Contoh kalimat tersebut secara tidak langsung memberikan motivasi agar setiap karyawan wajib mencapai target yang telah ditentukan oleh perusahaan. Dengan adanya pemberian reward berupa kenaikan gaji yang diharapkan oleh karyawan, tingkah dan sikap karyawan akan mengikuti mindset yang terbangun dalam otak karyawan, dengan begitu pemimpin perusahaan tidak perlu lagi mengingatkan karyawan akan capaian kinerja yang harus mereka raih setiap bulannya.

Selain kalimat motivasi berupa pemberian reward kenaikan gaji pemimpin dapat memberikan motivasi dengan penyampaian visi dan misi perusahaan ke depan dan apa hasil dari perusahaan yang dapat dinikmati oleh karyawan ke depan. Selain itu, sanjungan dalam bentuk kalimat sederhana juga dapat memberikan motivasi yang berarti bagi karyawan. Contohnya kalimat "Terima kasih sekali kepada mbak dan mas bersedia bekerja dengan baik disini dengan tetap menjadi karyawan yang 
mematuhi standar kerja serta loyal dalam segi waktu dan tenaga sehingga UMKM ini tetap berjalan bahkan berjalan lebih baik dari sebelumnya. Mbak dan Mas harus tetap semangat ya dalam bekerja supaya kita mampu bersaing dengan perusahaan lain yang lebih dulu berkembang dari kita, yakinlah kita pasti bisa menjadi seperti mereka". Jika karyawan diberikan motivasi dalam bentuk kalimat sanjungan seperti diatas maka karyawan akan merasa dibutuhkan dan menjadi lebih baik lagi dalam bekerja.

F. Gaya Kepeminpinan dalam Perusahaan Di era milenial sekarang gaya kepemimpinan yang diharapkan oleh karyawan adalah gaya kepemimpinan yang tidak kaku dan cenderung memberikan kepercayaan kepada karyawan untuk mengeksploirasi potensi yang ada dalam diri karyawan sendiri. Pada UMKM umumnya gaya kepemimpinan yang diharapkan adalah gaya kepemimpinan yang karismatik, situasional, dan inovatif.

Pemimpin yang berkarisma akan menjadi daya tarik tersendiri bagi karyawan dan menjadi motivasi dalam bekerja. Dengan karisma yang dimiliki karyawan akan lebih mudah mengikuti perintah pimpinan. Karyawan merasa bahwa pimpinannya memiliki rasa percaya diri yang kuat, dapat dipercaya, dan membuat karyawan kagum akan apa pun yang dikerjakan pimpinan.

Pemimpin yang situasional adalah pemimpin yang sangat cocok dengan UMKM karena pemimpin yang situasional lebih menekankan pada keadaan lingkungan tempat kerja, cara berkomunikasi dilingkungan kerja, dan lebih mudah menyesuikan dengan keadaan yang tiba-tiba berubah.

Pimpinan yang inovatif juga penting dimiliki oleh UMKM karena UMKM dituntut untuk selaku berperilaku kreatif agar bisa bertahan dan mampu berkembang menjadi lebih besar lagi. Inovasi yang dikembangkan dimulai dari hal yang sederhana kemudian merambah sedikit demi sedikit kepada hal-hal yang sifatnya dapat merubah perkembangan usaha menjadi lebih luas lagi.

\section{HASIL PENELITIAN}

Dari 10 UMKM yang diteliti, ditemui bahwa kalimat motivasi merupakan salah satu kunci utama meningkatkan kinerja karyawan. Karyawan pada UMKM sangat senang diberikan pengarahan dalam bentuk kalimat motivasi dan diberikan dukungan dalam bentuk kalimat dibandingkan dengan memberikan reward berupa benda yang bisa dipakai oleh karyawan. Karyawan merasa 
sangat dihargai dengan sanjungan atas prestasi kerja yang telah diraih.

Penggunaan motivasi dalam bentuk kalimat ini juga menghemat dana pimpinan dalam meningkatkan kinerja karyawan. Pimpinan cukup membuat kalimat yang dapat menggerakkan karyawan untuk bekerja sesuai dengan target yang diinginkan. Kalimat tersebut juga dapat merubah mindset karyawan yang awalnya bekerja tidak sesuai target menjadi bekerja melebihi target yang diharapkan.

Gaya kepemimpinan pemilik UMKM juga menjadi hal yang tidak kalah penting dalam menentukan kinerja karyawan. Banyak karyawan UMKM yang merasa nyaman dan semangat dalam bekerja apabila pemimpin bisa menyesuaikan dengan kondisi yang terjadi dilingkungan kerja. Pemimpin yang situasional menjadi tolak ukur juga bagi karyawan untuk bekerja sesuai target yang telah ditentukan. UMKM rata-rata hanya memproduksi barang dalam jumlah yang tidak terlalu besar. Rata-rata mereka hanya bisa mengirim barang ke luar kota atau luar propinsi yang masih berada di Pulau Jawa dengan jumlah yang terbatas. Pemimpin yang situasional menjadi penting dalam hal ini karena ada kalanya produksi menjadi sepi dan ada kalanya produksi juga ramai.

\section{KESIMPULAN}

Kalimat motivasi menjadi salah satu kunci utama dalam mencapai target kerja karyawan. Kinerja karyawan akan mudah ditingkatkan dengan cara tersebut. Dengan memberikan motivasi dalam bentuk kalimat pemimpin juga lebih menghemat waktu dan tenaga.

Gaya kepemimpinan yang paling tepat dalam meningkatkan kinerja karyawan adalah dengan gaya kepemimpinan yang situasional. Ada kemungkinan karena usaha yang dijalankan bersifat kecil hingga menengah sehingga gaya kepemimpinan yang dapat menghilangkan jarak antara pimpinan dan karyawan menjadi sangat cocok diterapkan dalam mencapai target UMKM.

\section{DAFTAR PUSTAKA}

Desky, H. 2014. "Pengaruh Etos Kerja Islami Dan Gaya Kepemimpinan Terhadap Kinerja Karyawan Rumah Makan Ayam Lepas Lhokseumawe" Jurnal Penelitian Sosial Keagamaan, Volume 8 Nomor 2.

Handoko, T. Hani. 2010. Manajemen. Yogyakarta: BPFE.

Mahsun, Mohammad. 2006. Pengukuran Kinerja Sektor Publik. Yogyakarta: BPFE.

Mangkunegara, A. P. 2011. Manajemen Sumber Daya Manusia. Perusahaan Percetakan Pertama. Jakarta : Penerbit Remaja Rosdakarya.

Moleong, Lexy J. 2005. Metode Penelitian Kualitatif. Bandung: Remaja Rosdakarya.

Putri, Sri Andika. 2017. "Pengaruh Pelatihan Dan Kalimat Motivasi Terhadap 
Jurnal OPTIMA II Sri Andika Putri dan Fitria Setyaningrum

Produktifitas Kerja Karyawan UMKM" Jurnal OPTIMA, Vol 1, No 1.

Sugiyono. 2017. Metode Penelitian

Kuantitatif, Kualitatif, dan Kombinasi

(Mixed Methods). Bandung: Alfabeta.

Sofyandi, H. 2013. Manajemen Sumber Daya

Manusia. Cetakan Kedua. Yogyakarta :

Graha Ilmu. 